\title{
Cross-Sectional Analysis of Critical Risk Factors for PPP Water Projects in China
}

\author{
Albert P.C. Chan, Patrick T.I. Lam, Yang Wen, Ernest E. Ameyaw, ShouQing Wang, Yongjian Ke
}

\begin{abstract}
During the past decades in China, the traditional state monopoly has experienced difficulties in meeting the huge demand for new infrastructure and improvement in service levels, engendering the growth of different forms and degrees of private sector involvement. Since the 1990s, China has started experimenting with the public-private partnership (PPP) delivery method in the water supply sector. However, many problems stemming from unsuccessful risk management have been encountered in PPP applications that have eventually led to project failure. This paper aims to identify and evaluate typical risks associated with PPP projects in the Chinese water supply sector. A literature review, a Delphi survey, and face-to-face interviews were used to achieve these objectives. Finally, a register of 16 critical risk factors (CRFs) of water PPP projects in China was established. The findings revealed that completion risk, inflation, and price change risk have a higher impact on Chinese water PPP projects, whereas government corruption, an imperfect law and supervision system, and a change in market demand have a lower impact on the water supply sector. The findings can help project stakeholders to improve the efficiency of privatization in public utility service and provide private investors with a better understanding while they participate in the enormous Chinese water market through the PPP mode.
\end{abstract}

Keywords: Public-private partnerships; Water supply sector; Risk ranking; Risk allocation

\section{Introduction}

\subsection{Background}

Since the 1980s, both developed and developing countries have turned to the private sector as a means to improve operational efficiencies of ill-performing public water utilities and leverage private sector capital (Haarmeyer and Mody 1998). Rivera (1996) explained that following the 1980s' debt crisis, private sector participation (PSP) or public-private partnerships (PPPs) gained a great deal of support from governments as a means to facilitate settlement of international debt through the proceeds generated from the sale (full divestiture) of state-owned enterprises and through cutbacks (as in other less radical forms of PPPs, to be discussed in a later section of this paper) in public financial support for state services, especially water. However, the 1990s saw ambitious sector reforms by various governments in an effort to turn around their public utilities. This is true in developing and transition economies for which the water sector is financially and operationally frail (Haarmeyer andMody 1997). Studies on urban water utilities in developing countries by the World

Copyright: Journal of Infrastructure Systems 2015. (C) 2016 Albert P.C. Chan, Patrick T.I. Lam, Yang Wen, Ernest E. Ameyaw, ShouQing Wang, Yongjian Ke. This is an Open Access article distributed under the terms of the Creative Commons Attribution 4.0 Unported (CC BY 4.0) License (https://creativecommons.org/licenses/by/4.0/), allowing third parties to copy and redistribute the material in any medium or format and to remix, transform, and build upon the material for any purpose, even commercially, provided the original work is properly cited and states its license.

Citation: Chan, A. P. C., Lam, P. T. I., Wen, Y., Ameyaw, E. E., Wang, S. Q., \& Ke, Y. (2015). Cross-sectional analysis of critical risk factors for PPP water projects in China. Journal of Infrastructure Systems, 21(1), 04014031. doi: 10.1061/(ASCE)IS.1943-555X.0000214

Corresponding author: Albert P.C. Chan; Email - bsachan@polyu.edu.hk 
Bank in the 1990s revealed that the cost recovery rate is only $35 \%$, the volume of unaccounted-for water is high and ranges from $40-60 \%$ of total water produced versus $10-20 \%$ of well-managed utilities, poor asset conditions are characterized by high leakage rates and water theft, there is low labour productivity due to overstaffing of public utilities — ranging from 10-20 employees per 1,000 connections compared with the global best practice of two to three workers per 1,000 connectionsand under-pricing occurs (Haarmeyer and Mody 1997, 1998). Strategies for PPPs in the water sector are promoted as a means to satisfy multiple sector and policy objectives, such as expanded access, improved service quality, leveraging private capital toward future investments, injecting economic efficiency and reducing the financial burden of governments, and promoting technological advances (Rivera 1996). Therefore, driven by financial constraints and public dissatisfaction with the belowstandard performance of public water utilities, governments have turned to the private sector for relief (Dailami and Klein 1997) because the private sector has been promoted as being able to leverage many capital resources and inject efficiencies into the utilities.

Annez ("Urban infrastructure finance from private operators: What have we learned from recent experience?," working paper, World Bank, Washington, DC) holds the view that the discussion of urban infrastructure investment is incomplete without discussing private sector participation, whereas Haarmeyer and Mody (1997) argue that private sector capital has relieved governments of financial constraints while improving operational efficiency. Focusing on the Asia-Pacific region, Estache and Rossi ("Comparing the performance of public and private water companies in the Asia and pacific region: What a stochastic costs frontier shows," working paper, World Bank, Washington, DC) concluded that the private sector is more efficient in the provision of water services than the public sector. In a comparative analysis of private and public water utilities in the United Kingdom and the United States, Hassanein and Khalifa (2007) reported better performance by the private sector regarding labour productivity, return on equity, and affordability of water rates by consumers.

Faced with escalating domestic and industrial water demand, limited public funding for water infrastructure development, disrepair of existing water supply infrastructure, and a pressing need for improved service and high operational efficiency (Meng et al. 2011), the government of China has embraced the private sector as a potential development partner in delivering water services and infrastructure. Private participation in public utility services in China can be traced from the early 1980s. With the rapid economic development and urbanization over the past two decades, a massive demand for new infrastructure and improved service levels in the water supply sector make it increasingly important and necessary for the government to turn to the private sector (Zhong et al. 2006). As a result, the government has strived to create an enabling environment for private investors. The scope of private participation ranges from full privatization, which is the complete transfer of assets and responsibility to the private sector, to PPPs, in which the assets remain with the public sector but the government and the private investor collaborate to provide services to the public (Lee 2003). Today, China is the fastest-growing market for private water operators following the abolishment of the ban on foreign investors' managing and operating water utilities in 2002. Several PPP contracts between Chinese local governments and private consortia (including both international water operators and domestic investors) have been implemented since then (Marin 2009).

Analysts maintain that private sector capital and initiative could only help to improve operational efficiency and fill the investment gap if both external (e.g., regulatory, foreign exchange, and so forth) and internal (e.g., construction, operation, and so forth) project risks are identified and sensibly allocated to the party with adequate resources to manage and mitigate them (Haarmeyer and Mody 1997). This is a condition that must be satisfied in any PPP arrangement. Learning from the challenges (collectively risks) of PPPs in the 1990s, as well as a series of highly publicized contract 
terminations (Marin 2009), the private sector has become mindful of the plethora of risks relevant to water supply projects (Wibowo and Mohamed 2010). Water projects are viewed as risky investments - especially in developing countries - and are characterized by large initial fixed cost, regulatory difficulties, high sunk costs, long payback periods for investments, multiple and (sometimes) conflicting public policy objectives, asset condition uncertainty, inadequate performance of the private sector, and long lead times for upgrading (Idelovitch and Klas 1997; Abdul-Aziz 2001). In China, compared with traditional construction projects, there is a higher risk exposure for PPP stakeholders, such as high capital outlay, long lead time, and long-lived assets with little value in alternative use (Zayed and Chang 2002), mainly owing to the complexity compounded by the unique features and extents of the disciplines, public agencies, and stakeholders involved (Tiong 1995). Yuan et al. (2008) reported that the many risks related with politics, the economy and regulations in China, and the lack of effective risk management for PPPs results in many failures in practice. Particularly, water PPPs are fraught with several problems when potential risks are not identified and equitable risk sharing or allocation remains vague (Wibowo and Mohamed 2010). To this end, some authors [e.g., Wibowo and Mohamed (2010), Idelovitch and Klas (1997), and Rivera (1996), among others] have undertaken country case studies with the aim of presenting the most critical risk factors (CRFs) and best practices associated with water PPP contracts. Thus, the high risk exposure inherent with PPP schemes demands more attention from the stakeholders (including the public sector client and the private sector bidders) in analysing and managing risks in China. However, a comprehensive analysis on the CRFs in water PPP projects for China's specific circumstances is still lacking.

Thus, the objective of this paper is to identify the CRFs in Chinese water PPPs and analyse the preferred risk allocation between the public sector client and the private sector company. The findings presented in this paper are expected to contribute to the development of PPPs in the Chinese water supply sector and provide valuable information and risk management implications for the government and the interested investors to better understand the risk issue associated with Chinese water PPP projects in particular.

After presenting the forms of PPPs in the Chinese water sector, the aim and methodology of the study are discussed. The survey process and results are given in detail. Finally, a discussion of the results and conclusions of the study are presented.

\subsection{PPPs in China's Water Supply Sector: Taxonomy and Application Status}

During the 1990s, the water supply grew at an annual rate of only 3\%, which was substantially lower than the double-digit growth of the economy (Chen 2009). The huge water consumption driven by further urbanization and industrialization in China is expected to continue to increase as the economy grows.

Public-private partnership application in the water supply sector was promoted by the Chinese government as an experimental approach. In the mid-1990s, the government attempted to introduce the build-operate-transfer (BOT) approach into urban infrastructures (power plants, highways, water supply, and so forth). Subsequently, the State Development and Planning Commission (SDPC) approved three BOT projects in 1996, including the Chengdu No. 6 water supply BOT plant, the Guangxi Laibin power BOT plant, and the Changsha Wangcheng power BOT plant (Chen and Doloi 2008).

Full-fledged private involvement in the water sector and other utility sectors was encouraged starting in late 2002 (Zhong et al. 2008). In December 2002, the "Opinions on Accelerating the 
Marketization of Public Utilities” (Ministry of Construction 2005) started the foreign and domestic investors' involvement in water and other public sectors. Up to July 2005, a total of 152 water supply projects and 200 wastewater treatment projects involved private participation (Ministry of Construction 2005).

The concept of PSP or PPPs encompasses a variety of policy approaches (Rivera 1996). In the Chinese experience, at one end of the spectrum stands sale/full divesture-full sale of the state asset and control to the private sector (Hemming and Ali 1988), and at the other end are less radical forms of PPPs such as management contracts, concessions, joint ventures, and so forth. Fig. 1 shows the distribution of several common forms of PSP in water supply and wastewater projects in China (Ministry of Construction 2005). The joint venture approach (including the Sino-foreign joint ventures) has the largest percentage in the water supply sector, accounting for $51 \%$ of the 152 privatized projects. The Greenfield modes of private sector participation, including BOT, and transfer-operate-transfer (TOT) contracts dominate the wastewater sector, accounting for $59 \%$ of the 200 projects. The Greenfield modes of PPP projects involve the development of new infrastructure or asset (Rall et al. 2010), of which "ownership rests with the private sector and is transferred to the public-sector client” on expiration of the contract (World Bank 2010), such as BOT/build-ownoperate-transfer (BOT/BOOT)-type contracts.

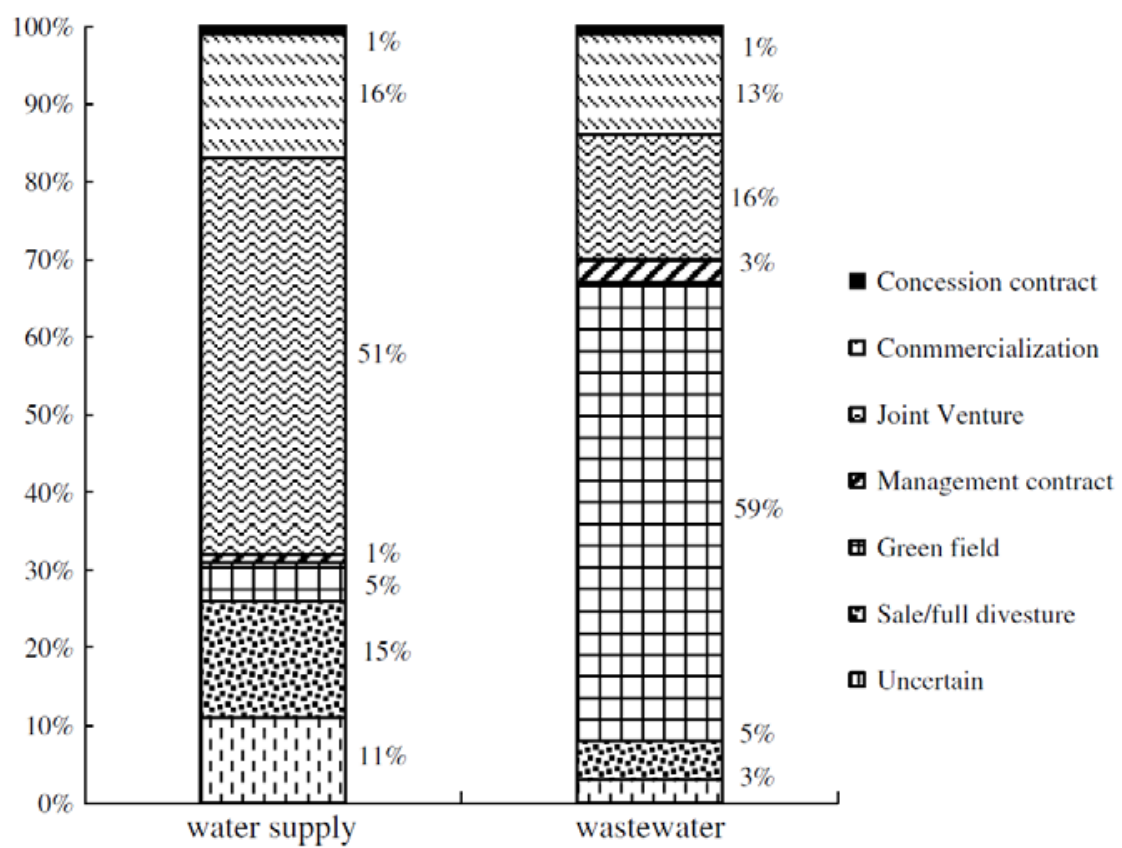

Fig. 1. Distribution of major types of public sector participation in China's water supply sector (data from Ministry of Construction 2005)

Under concession contracts, the ownership of the water asset or infrastructure rests with the public sector client, whereas the operation, management, financial, and investment responsibilities in the expansion and maintenance of the utility's asset are outsourced to the private sector company (called the concessionaire) for a period of time (often 20 years or more) (Baurmert and Bloodgood, "Private sector participation on the water and wastewater services industry," working paper, U.S. International Trade Commission) with the aim of improving the efficiency of the utility. In management contracts, asset ownership, investments, and financing responsibilities are borne by the public sector, whereas the day-to-day operation of the water utility rests with the private partner, with little or no financial commitments and a short duration of up to 5 years. In countries that are considered risky investment destinations, management contracts are preferred by the private sector (Baurmert and Bloodgood, "Private sector participation on the water and wastewater services 
industry,” working paper, U.S. International Trade Commission). A joint venture arrangement is desirable where a greater level of private sector involvement than in lease or management contracts is deemed necessary (Idelovitch and Klas 1997). The arrangement calls for the public sector agency (e.g., a public water utility) and the private company to incorporate a company under the commercial code, but the private partner plays a major role in the daily management of the newly formed firm (Idelovitch and Klas 1997). On the other hand, sale/divestiture is not a partnership or PPP arrangement and involves an outright sale of a public water utility to the private sector firm(s). Some literature describes it as full privatization, although it is limited in the global water industry, and the intention may include raising money for governments (Rivera 1996; Idelovitch and Klas 1997). A classic example is the U.K. water industry, where water companies are owned and operated by the private sector.

\subsection{Public-Private Partnership Project Risk}

Public-private partnership modes are usually subjected to more risks than other traditional construction projects, mainly because different project objectives and interests are expected by a wide range of stakeholders (Shen et al. 2006). The unique features, external uncertainties, and multidisciplinary character involved, as well as the public agencies' and stakeholders' participation, compound the PPP projects' complexity (Thomas et al. 2003). The identification, classification, and presentation of a comprehensive list of critical risks will provide PPP project practitioners with a useful tool for analysing the project's potential impact and considering appropriate strategies to mitigate their effects (Xenidis and Angelides 2005).

The experience of PPP projects in China's urban water infrastructure has exhibited many problems (Zhong et al. 2008). Therefore, it is necessary to understand the risks and their causes for successful completion of future PPP projects. The works by Sachs et al. (2007), Zhong et al. (2008), Wang et al. (1999, 2000), Zhang and Kumaraswamy (2001), and Wang (2002) highlight the following risk factors of PPP application in China:

- The lack of a unified and sound legal framework for PPP: The existing policies and regulations lack uniformity. For example, the tendering documents for PPP projects in China vary from project to project and from province to province without a standardized model. This is unhealthy for PPP development in China.

- The risk of creditworthiness of local governments: Due to the lack of experience and knowledge in PPP, some local governments have tried to attract foreign investment through making unrealistic guarantees to the private companies. On one hand, this adds risks to the local governments, as it may lead to high cost to accomplish the contracts. On the other hand, if the local government fails to honour the contract, it adds risks to the private sector. Lawsuits to obtain compensation from the private sector will be unavoidable.

- The risk of a fixed investment return to investors: The issue of fixed investment return was applied in the earlier stage of BOT projects in China, owing to the local governments' limited experience and knowledge. These decisions led to some huge and disproportionate profits by investors. After intensifying control over foreign exchanges and loans in the late 1990s, the General Office of the State Council promulgated a specific circular in 2002 to correct the fixed investment return by buying back all shares of foreign investors, transferring foreign investment into foreign loans, or cancelling contracts with often severe losses. For the investors, this hampers the long-term security for PPP investment in China.

- The risk of regulating macroeconomic control and intervention from the central government: Adjustment in macroeconomic policy and market intervention by the central authorities may affect the economic feasibility of PPP projects. For example, the adoption of the stronger- 
power policy and the power market reorganization from 1998 to 2000 in China disrupted many power projects (Sachs et al. 2007).

- Corruption of local officers: It is critically essential to get cooperation and assistance from the government bureaucrats, especially according to the Chinese culture of guanxi (relationship). However, investors are under great pressure to spend a great deal of money to establish guanxi with the local officers. This has also hampered the efficiency of the companies' operation and management as well as profits.

A number of studies have focused on the identification and management of risks associated with PPP projects (Li et al. 2005; Wiguna and Scott 2006). Specifically, the work by Sachs et al. (2007) is limited to only six political risks - currency inconvertibility and transfer restriction; expropriation; breach of contract; political violence; legal, regulatory, and bureaucratic risks, and nongovernmental action risks - associated with PPP infrastructure projects in general. Furthermore, the study recorded a low response rate, with only 29 respondents in an international survey, thereby limiting its ability to generalize findings. There is, however, a paucity of study material on Chinese PPP projects, especially on the water supply sector. Therefore, further investigations are needed to identify and evaluate the CRFs in practice and highlight the implications for management to stakeholders.

\section{Research Aim and Methodology}

The risks associated with the PPP mode for different infrastructure sectors vary. The identification of CRFs according to the specific sector will provide practitioners with more pertinent information in analysing the project's potential risks and considering appropriate strategies to manage its effect. Therefore, the aim of this paper is to report on the CRFs for one type of PPP project-water supply and treatment PPP projects-in Mainland China.

The methodology for this research was a four-stage process: (1) extensive literature review on risk identification and evaluation in PPP projects, (2) general data collection on water PPP CRFs in China through a two-round Delphi survey, (3) face-to-face interviews with industrial practitioners in water PPP applications and factual data collection on water PPP CRFs, and (4) data comparison and integration to form a CRF register for Chinese water PPP projects.

\section{Survey Description}

Data collection for this research includes a Delphi survey and face-to-face interviews.

\subsection{Delphi Survey}

The Delphi technique is a method that uses a series of questionnaires interspersed with information feedback in the form of written summaries (Russell 1993). The Delphi technique is used to allow the experts to express their views freely without the influence of personal status, to enable the alteration of personal views without embarrassment, and to allow the combination of many opinions into a collective response (Beech 1999). The Delphi method is particularly useful in situations where objective data are unattainable, there is a lack of empirical evidence, experimental research is impractical or unethical, or the heterogeneity of the participants must be preserved to ensure the validity of the results (Hallowell 2009). The authors chose to consult experts and practitioners due to the fact that literature on practical risk assessment (frequency of occurrence and severity) in water PPP projects in China is patchy, while it is possible to get a good number of practitioners and experts with considerable hands-on experience in the specialized subject. 
Underlying issues in preparing a Delphi survey include: (1) the definition and selection of the panel of experts, (2) a desired number and format of rounds, and (3) the formulation of the questionnaire in each round (Manoliadis et al. 2006). The Delphi method as an iterative forecasting process is characterized by three key features (Dickey andWatts 1978): anonymity of respondents, iteration with controlled feedback, and statistical response. Of course, there are different ways to conduct a Delphi survey - through committee meetings, conferences and seminars, mail and e-mails, and conference telephone calls (Linstone and Turoff 2002; Chan et al. 2001; Rixon et al. 2007). In this study, remote participants located across China were consulted through e-mails. A similar approach was adopted by Moglia et al. (2009), in which remote participants were contacted via Survey Monkey software and e-mails. The Delphi panellists for this study were anonymous to one another while responding to the two rounds of questionnaires. Chan et al. (2001) argue that the iterative process produces new information for panellists in each round and affords them the chance to amend their assessments so that biases or personal, subjective opinions are minimized.

The Delphi technique is widely adopted in many complex areas where consensus building or convergence of opinion on a practical subject is required (Linstone and Turoff 1975; Chan et al. 2001). It has been successfully applied in several areas, including selection of procurement systems (Chan et al. 2001), sustainable construction (Manoliadis et al. 2006), risk allocation (Ke et al. 2010; $\mathrm{Xu}$ et al. 2010a), and risk assessment (Xu et al. 2010b). Therefore, the Delphi method is suited for this study to determine the risk impact on PPP water supply projects in China.

\subsection{Selection of Expert Panel}

The credibility of the study is closely tied to the careful selection of panellists and the formulation of the survey questions (Goldstein 1975; Chan et al. 2001). Because high credibility of the study necessitates thorough knowledge and sound experience about PPPs, a purposive approach was adopted to select the panel of experts (Edmunds 1999; Morgan 1998), who satisfied at least one of the following criteria (Ke et al. 2010): 1) Having extensive working experience in PPP projects in China; 2) Having current/recent and direct involvement in risk management of PPP projects in China; and 3) Having a sound knowledge and understanding of the concepts of PPP risks. Responses were obtained from respondents with rich, practical hands-on experience in PPPs so that the credibility of this study was ensured.

The first-round survey questionnaires were sent to approximately 580 target respondents in China. A total of 105 experts responded to the invitation and participated in the first-round survey. Maintaining a high response rate remains a major challenge in Delphi method application (Robinson 1991). In this study, refusal to participate [Peninsula Research and Development Support Unit (RDSU) 2003] may be one reason for the low response rate. An additional reason includes the specialized nature of the study. Those who failed to meet the selection criteria could be many, as PPP practice in China is not mature, and participants with comprehensive knowledge and experience are lacking (Chan et al. 2010; Meng et al. 2011; Sachs et al. 2007). Respondent pre-notification (Mehta and Sivadas 1995) and a reminder message (Sheehan and Hoy 1997) for e-mail surveys are crucial and could increase the response rate for the study in Round 1 . The latter could increase the response rate by 25\% (Sheehan and Hoy 1997). Ninety-three experts completed the second-round questionnaire, representing a response rate of $89 \%$. Table 1 lists general information about the experts. 
Table 1. General Information about the Delphi Experts

\begin{tabular}{lc}
\hline Role of survey respondents & \\
\hline Category & Percentage \\
\hline Government & 14.0 \\
Industrial sector & 37.6 \\
Academic sector & 48.4 \\
Total & 100 \\
\hline
\end{tabular}

Type of PPP projects with which the survey respondents have been involved

\begin{tabular}{lc}
\hline Category & Number \\
\hline Transportation & 27 \\
Water & 17 \\
Power & 13 \\
School & 10 \\
Sport & 7 \\
Housing & 5 \\
Hospital & 4 \\
Other & 10 \\
\hline
\end{tabular}

\begin{tabular}{lc}
\hline \multicolumn{2}{c}{ Industrial experience of survey respondents } \\
\hline Category & Percentage \\
\hline 5 years or less & 17 \\
6-10 years & 10.6 \\
$11-15$ years & 27.7 \\
More than 16 years & 44.7 \\
\hline
\end{tabular}

\begin{tabular}{lc}
\hline \multicolumn{2}{c}{ Public-private partnership experience of survey respondents } \\
\hline Category & Percentage \\
\hline None & 13.6 \\
1-2 years & 25.0 \\
3-5 years & 45.5 \\
More than 6 years & 15.9 \\
\hline
\end{tabular}

\subsection{Survey Process}

A total of 34 risk factors (Table 2) affecting Chinese PPP projects were identified through an intensive literature review; thus, a comprehensive list was established and reported in a recent publication (Ke et al. 2010). These risk factors were adopted in this study and categorized into 10 critical risk groups (CRGs): political risk, economic risk, legal risk, social risk, nature risk, construction risk, operation risk, market risk, relationship risk, and other risk. 
Table 2. Ranking of CRFs of PPP Projects in Chinese Mainland

\begin{tabular}{|c|c|c|c|c|c|}
\hline Ranking & Risk factor & Probability & Severity & Impact $^{\mathrm{a}}$ & Normalization $^{\mathrm{a}}$ \\
\hline 1 & Government intervention & 3.90 & 3.92 & 3.86 & 1.00 \\
\hline 2 & Poor public decision-making process & 3.59 & 3.70 & 3.63 & 0.81 \\
\hline 3 & Government corruption & 3.57 & 3.68 & 3.59 & 0.78 \\
\hline 4 & Imperfect law and supervision system & 3.59 & 3.53 & 3.54 & 0.74 \\
\hline 5 & Public credit & 3.24 & 3.76 & 3.44 & 0.67 \\
\hline 6 & Subjective project evaluation method & 3.35 & 3.57 & 3.44 & 0.66 \\
\hline 7 & Interest rate fluctuation & 3.47 & 3.39 & 3.41 & 0.63 \\
\hline 8 & Conflicting or imperfect contract & 3.37 & 3.48 & 3.40 & 0.63 \\
\hline 9 & Change in market demand (noncompetition factor caused) & 3.25 & 3.60 & 3.40 & 0.63 \\
\hline 10 & Insufficient project finance supervision & 3.16 & 3.69 & 3.39 & 0.62 \\
\hline 11 & Operation cost overrun & 3.27 & 3.54 & 3.38 & 0.61 \\
\hline 12 & Project/operation changes & 3.45 & 3.30 & 3.35 & 0.59 \\
\hline 13 & Foreign exchange fluctuation & 3.40 & 3.39 & 3.34 & 0.58 \\
\hline 14 & Inflation & 3.41 & 3.38 & 3.33 & 0.57 \\
\hline 15 & Completion risk & 3.20 & 3.49 & 3.32 & 0.56 \\
\hline 16 & Price change & 3.11 & 3.49 & 3.27 & 0.52 \\
\hline 17 & Delay in project approvals and permits & 3.25 & 3.30 & 3.24 & 0.50 \\
\hline 18 & Inadequate competition for tender & 3.20 & 3.35 & 3.24 & 0.50 \\
\hline 19 & Third-party delay/violation & 3.17 & 3.24 & 3.19 & 0.46 \\
\hline 20 & Lack of supporting infrastructure & 3.03 & 3.41 & 3.19 & 0.46 \\
\hline 21 & Inability of concessionaire & 2.86 & 3.69 & 3.20 & 0.46 \\
\hline 22 & Concessionaire change & 3.03 & 3.40 & 3.18 & 0.45 \\
\hline 23 & Legislation change & 2.82 & 3.55 & 3.13 & 0.41 \\
\hline 24 & Expense payment risk & 2.94 & 3.40 & 3.13 & 0.41 \\
\hline 25 & Organization and coordination risk & 3.15 & 3.17 & 3.13 & 0.41 \\
\hline 26 & Land acquisition & 2.77 & 3.43 & 3.06 & 0.35 \\
\hline 27 & Financing risk & 3.51 & 3.74 & 3.06 & 0.35 \\
\hline 28 & Environment risk & 2.96 & 3.20 & 3.05 & 0.34 \\
\hline 29 & Market competition (uniqueness) & 2.81 & 3.34 & 3.02 & 0.32 \\
\hline 30 & Force majeure & 2.45 & 3.57 & 2.89 & 0.21 \\
\hline 31 & Material/labor nonavailability & 2.74 & 3.11 & 2.90 & 0.22 \\
\hline 32 & Change in tax regulation & 2.76 & 3.11 & 2.90 & 0.22 \\
\hline 33 & Public opposition & 2.55 & 3.11 & 2.77 & 0.11 \\
\hline 34 & Unforeseen weather/geotechnical conditions & 2.54 & 3.05 & 2.75 & 0.10 \\
\hline 35 & Unproven engineering techniques & 2.53 & 3.03 & 2.73 & 0.08 \\
\hline 36 & Nationalization/expropriation & 2.23 & 3.47 & 2.70 & 0.06 \\
\hline 37 & Residual risk & 2.62 & 2.70 & 2.63 & 0.00 \\
\hline
\end{tabular}

Note: Normalization value $=($ average actual value - average minimum value $) /($ average maximum value - average minimum value $)$.

${ }^{\mathrm{a}}$ Impact $=(\text { probability } \times \text { severity })^{0.5}$.

This Delphi survey consisted of two rounds of questionnaires administered within a time frame of 5 months (Fig. 2). In Round 1, the questionnaire was e-mailed to all experts with the following instructions: “(1) Please estimate probability of occurrence based on a 5-point scale (where 1 = very low probability of occurrence and $5=$ almost certain to occur); (2) Please estimate the severity of the risk described on a scale of 1 to 5 (where $1=$ no serious influence on the project and $5=$ catastrophic, where the project would be aborted); (3) Please include an estimate of the probability of occurrence and severity of any new additional risk factors which you thought of as critical risk factors in Chinese PPP/BOT projects but were not included in the questionnaire.” The answers listed in the returned questionnaires were collated and qualitatively analysed using the Statistical Package for Social Sciences (SPSS) software. The statistic results and three new risk factors identified by the respondents -including subjective project evaluation method, insufficient project finance supervision, and concessionaire change-formed the base of the Round 2 questionnaire and were fed back to the respondents.

The purposes of the Round 2 questionnaire were to allow the experts to review the overall response from Round 1. In the questionnaire, the mean values of each risk factor's probability of occurrence and severity were listed, and the respondents were given an opportunity to adjust their own scores after reviewing the average scores of other respondents. By using this feedback and iteration process, the establishment of the CRFs for PPP projects would be more accurate. 


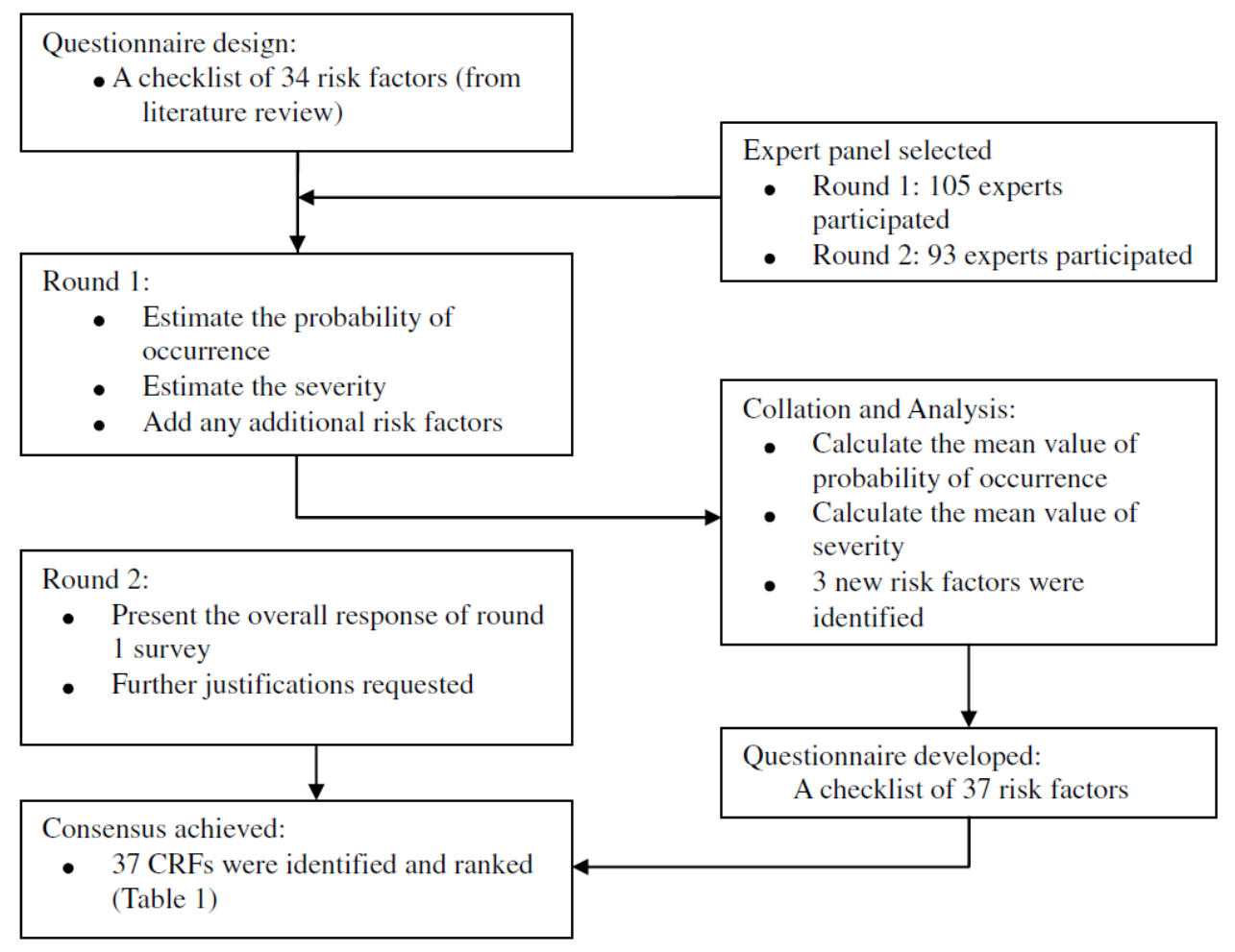

Fig. 2. Process of two-round Delphi survey

\subsection{Survey Results}

For each risk factor, the risk impact indexes on the project's performance were then calculated by taking the square root of the product of the probability of occurrence and severity (impact = $\sqrt{\text { probability } \times \text { severity }}$ ) [mean value $\in(1,5)$ ] and were ranked in descending order, as shown in Table 2. After two rounds of the Delphi survey, risk factors with normalized values equal to or greater than 0.50 (Table 2) were selected as CRFs. This approach follows a similar approach adopted in previous studies (Xu et al. 2010b). This approach further makes it possible to apply the factor analysis technique when required (Toor and Ogunlana 2008).

\subsection{Face-to-Face Interviews}

Face-to-face interviews with practitioners in the Chinese water supply sector were conducted in May 2009. A total of 15 industrial practitioners from eight water plants in the Beijing, Jiangsu, and Liaoning provinces were surveyed in this study.

The purpose of adopting the interview technique with a structured questionnaire is to ensure that answers to common questions can be analysed and compared, yet flexibility was provided to allow respondents to provide in-depth answers and particularly interesting aspects of their experience. This can help to achieve a higher participation rate because interviewees only need to give verbal comments rather than fill up a questionnaire with long answers.

The questionnaire for the interviews was specially designed into three parts: (1) background of the respondents and the PPP project with which s/he was involved, (2) assessment of the impact of the risks if they did occur on the project using a five-point scale (where $1=$ no serious influence on the project and 5 = catastrophic, where the project would be aborted), and (3) open-ended questions to 
investigate how these risks had an impact on projects. As mentioned previously, these open-ended questions allowed interviewees to have greater freedom in sharing their experience and knowledge.

\section{Discussion}

In the interview, a CRF register on Chinese water PPP projects was proposed (Table 3). This risk register consisted of the top 16 risk factors faced by private companies and public agencies in the water supply sector, as obtained through the questionnaire survey.

Table 3. Ranking of CRFs for Chinese Water PPP Projects

\begin{tabular}{lcc}
\hline Ranking & Risk factor & Impact \\
\hline 1 & Financing risk & 4.71 \\
2 & Completion risk & 4.43 \\
3 & Subjective project evaluation method & 4.33 \\
4 & Government intervention & 4.14 \\
5 & Poor public decision-making process & 4.00 \\
6 & Public credit & 4.00 \\
7 & Inflation & 3.33 \\
8 & Operation cost overrun & 3.29 \\
9 & Interest rate fluctuation & 3.20 \\
10 & Conflicting or imperfect contract & 3.20 \\
11 & Government corruption & 3.17 \\
12 & Imperfect law and supervision system & 3.00 \\
13 & Project/operation changes & 2.83 \\
14 & Insufficient project finance supervision & 2.75 \\
15 & Foreign exchange fluctuation & 2.57 \\
16 & Change in market demand & 1.88 \\
& (not caused by competition factor) & \\
\hline
\end{tabular}

Comparing the CRFs of PPP projects assessed by the Delphi participants, it is interesting to find that the categories of completion risk, inflation, and price change have a higher impact on Chinese water PPP projects, whereas government corruption, an imperfect law and supervision system, and change in market demand have a lower impact on the water supply sector.

\subsection{Completion Risk}

Completion risk arises when the project cannot be completed at all or as scheduled, and water projects under PPP arrangement are susceptible to this risk simply because they require infrastructure facilities (Public Private Partnership Centre 2012). In a similar comparative study in China, completion risk is ranked highly for water and wastewater projects compared with power and energy and transportation projects (Cheung and Chan 2011). This could explain why the risk has a high impact of 4.43. Private investors pay more attention to the completion risk. On one hand, a private company has to compensate the city government according to the concession contract if they cannot complete the project construction on time. On the other hand, because the total period of construction and operation is stipulated in the contract, delays in project construction will definitely lead to a shortened operation life of the project, which will directly reduce the investors' income. If projects fail to start operation according to schedule, the private company will not have sufficient cash flow to pay for the debt to the bank, resulting in an extension of loan time and interest increase, which increases operation cost and reduces the profits of the private sector. In analysing the risks relevant to water PPP projects, Pribadi and Pangeran (2007) found that delays in completion result from an absence of coordination of the contractors, an inability to secure standard planning approvals, and a 
delay in granting (or failure to grant) contractual land-use rights. However, the interviewed water projects were all completed on time; some were even completed ahead of schedule.

Several analysts (Delmon 2009; Public Private Partnership Centre 2012) suggest that completion risk should be allocated to the private sector (the project company), except in circumstances where a delay is caused by the public sector client (Delmon 2009). In this study, the interview respondents suggested several solutions for transferring this risk-for example, signing Supply Contract on a fixed-price basis with material suppliers or signing Installation Contract with the contractor, including a liquidated damages clause by which the risk will be assigned to material suppliers and installation contractors. Engineering delays caused by irresistible force can be transferred to insurance companies.

\subsection{Inflation}

Hammami et al. ("Determinants of public-private partnerships in infrastructure,” working paper, International Monetary Fund, Washington, DC) assert that lower and controlled inflation is conducive to macroeconomic stability and leads to more PPPs. This is because inflation [assessed to have an impact of 3.33 (Table 3)] may cause a sharp rise of labour cost and material prices, leading to an increase in the project construction and operation cost. Even though some project companies regarded the current inflation rate in China as acceptable and they can undertake the risk, most of the interviewees still maintained a cautious attitude on this risk. In the PPP mode, private investors reduce the influence of inflation risk mainly through adjusting the water price. In the concession agreements, they usually propose water price adjustment provisions by regulating the adjustment period and methods or stipulating that the water price is related and adjusted with the retail price index periodically, thereby transferring the inflation risk to the government.

\subsection{Price Change}

Price adjustment uncertainty is a major risk facing water operators in China (Choi et al. 2010). Idelovitch and Klas (1997) explain that the risk arises from the reluctance of governments to raise tariffs (which may have been provided for in the contract), particularly before election. In China, the price of the water is fixed by an agreement between the project corporation and water conservancy department of the local government. According to the agreement, if the price of raw water increases, the price of supplied water can be adjusted or the concession period can be extended in order to compensate for the loss. However, most privatization ventures in the water supply sector failed due to the public's strong resistance following sharp price increases (Hall and Lobina 2005). For example, the 1999 40-year water and sanitation concession (awarded to Aguas del Tunari) in Cochabamba, Bolivia, was terminated in April 2000 following pubic protest due to a tariff increase of over 200\% (Lobina 2000). According to interviews with the practitioners on water PPP projects, the current market price for providing water services is still much lower than the full cost. Where prices are too low, the private operator may withdraw: in 1999, Biwater withdrew from a proposed water privatization project in Zimbabwe due to consumers' inability to pay economic water prices that are realistic to cover the operator's desired profit margin and expenses (Bayliss 2002).

Since the launch of China's economic reforms, infrastructure has been increasingly commercialized. However, in many cities of China, the provision of infrastructure and public services is still considered public welfare and the government's responsibility instead of an economic good. Therefore, changing the market prices involves many social, economic, and political issues, which all limit the commercial viability in privatization practices (Chen and Doloi 2008). Taking urban water as an example, the matter of price change must first be approved by the Price Bureau. The 
public hearing on the adjustment of public service and product price is a complicated and timeconsuming process, which usually makes price adjustment more difficult to achieve. Faced with this risk, water operators tend to focus more on reducing unaccounted for water levels so that savings could be made [Global Water Intelligence (GWI) 2004].

\subsection{Government Corruption}

In a study published by Cheung and Chan (2011), corruption in water PPPs was not viewed as a serious threat to the success of contracts compared to the power and energy and transportation PPP projects. They could not explain this difference. In this study, government corruption was a sensitive topic in the interviews. Many project practitioners answered this question very carefully and did not see corruption as a potential risk in their respective projects. Counting on the prevalence of corruption in worldwide water contracts (Hall and Lobina 2004), it can be argued that the low impact of corruption in China's water projects is attributable to the fact that corruption does not occur in daylight; it is hard, if not impossible, to determine via contract language (Wang and Ke 2009). The private sector is very cautious when handling relationship issues with the government. Sachs et al. (2007) claimed that any BOT/PPP projects cannot proceed successfully without good cooperation and assistance from the local government, but sometimes the cost is too much for the investors due to the corruption of some government officers. This also has a negative influence on the efficiency of the companies’ operation and management as well as profits.

The cost of corruption is borne by consumers in the form of increased tariffs and poor service levels, as illustrated in the Grenoble concession corruption case. In 1995, a French court of law found that an ex-mayor and government minister received payments from a French international water company-Lyonnaise des Eaux-in exchange for Grenoble’s 25-year water concession to the company's subsidiary, Compagnie de Gestion des Eaux du Sud-Est (COGESE). The corrupted deal, totalling more than FF 19 million, was to support the ex-minister's electoral campaign (Hall 2001). The regional auditor revealed that "the complete life-cycle of the contract had cost local consumers and taxpayers more than FF 1 billion (US\$150 million)” (Hall and Lobina 2001, 2004).

\subsection{Imperfect Law and Supervision System}

The practitioners in the interviews considered the risk of an imperfect law and supervision system to have less significance in the water PPP projects. They stated this even though the development of a legal and supervision framework governing PPPs in China is still in its infancy. Similar observations were made by Chen and Doloi (2008) and Zhong et al. (2008)—both legal and regulatory frameworks for BOT/PPP remain vastly inadequate in the Chinese context. Cheung and Chan (2011) reported that imperfect law and supervision risk are of major concern in transportation projects in China. This problem is gradually being surmounted by the promulgation of the governing laws, including highway law, power law, and telecommunications law, in recent years (Lee and Sung 1998). The danger lies in the fact that these laws are poorly enforced or not enforced at all (Cheung and Chan 2011). Both the Maanshan (joint venture) and Shenyang water supply projects suffered failed marketization practices due to frequent changes in policies and decisions of the local governments (Zhong et al. 2008). Since the mid-1990s, the central government has carried out various economic and legislative policies and regulations, aiming at attracting private sector involvement and foreign capital investment to the public sector. The promulgation of the Circular on Attracting Foreign Investment through BOT Approach and the Circular on Major Issues of Approval Administration of the Franchise Pilot Projects with Foreign Investment were considered the debut legal ground for private sector and foreign capital investment in Chinese infrastructure.

Subsequently, the government conducted various policies and regulations on a sector-by-sector basis 
(Lee and Sung 1998). Despite the improvement of regulatory regime for PPP projects in general, the development of a legal basis for PPP projects in water services has been quite slow and is still underdeveloped in China. The practitioners claimed that it is essential to establish a specialized legislation framework at the national level, which is expected by the private investors and local governments. In the absence of reliable laws and regulatory systems, the success of PPP projects may depend on the commitment of both parties to overcome challenges over the concession period.

\subsection{Change in Market Demand}

According to the interview results, the change in market demand risk has less influence on the water supply sector. The main reason is that there is an increasing demand for water service infrastructure in China. Several factors have led to a massive demand for new infrastructure in the water supply sector in China. One factor is the increasing demand for domestic and industrial water consumption accompanying the rapid urbanization and industrialization in China. Estimates from the National Bureau of Statistics (NBS) (2007) indicate that the urban population grew from 373.04 million in 1996 to 577.06 million in 2006, and the percentage of the Chinese urban population shot up from 29.37 to $43.90 \%$ in the same period, with an annual growth rate of 5.47\% (Meng et al. 2011). As a direct effect, the domestic water consumption expanded from 16.71 billion tons in 1996 to 22.20 billion tons in 2006 (NBS 2007), indicating a 3.29\% annual growth rate in residential water supply (Meng et al. 2011) and creating a significant imbalance between residential (urban) water supply and demand. The domestic and industrial water consumption is predicted to grow by $60 \%$ over 50 years up to 800 billionm3=year (Lee 2003). As a result, the increasing demand provides a good opportunity for foreign capital and private investors to participate in the Chinese water infrastructure market.

In practice, water concessions may include a guarantee on a fixed rate of return so as to shield private operators from revenue risks in the form of automatic price adjustment in response to changes in water demand or take-or-pay arrangements - the Chengdu (China) and Yuvacik (Turkey) water projects are typical examples (Lobina 2005). The Yuvacik BOT water scheme (the first PPP project in Turkey) was designed and constructed to supply water to the Izmit municipality and Istanbul over a 15-year period at a negotiated price. On the grounds of high tariffs, some municipalities (including the Izmit municipality, which promised to pay for 142 billionm3=year) and industrial consumers refused to buy water from the scheme (Hall and Lobina 2004; Başaran 2012). The Turkish government, according to the off-take agreement, paid for the quantity of water that was not consumed (Başaran 2012). In this study, it was found during the interviews that some private companies mitigated this risk through signing a take-or-pay agreement with the local government, which stipulated that the government will pay for a minimum water quantity to the water factory irrespective of actual consumption (or the government guaranteed an allowance to the contractor if the actual water demand is less than predicted). Where the growing imbalance between demand and supply is not curbed, future water prices are likely to be forced up following the law of supply and demand. This will bring affordability and water scarcity risks to the fore.

\section{Conclusions}

In China, the extreme shortage of infrastructure has the potential to suffocate economic growth and social development. The insufficiency of capital for financing the new public utilities makes the Chinese government turn to the private investors and foreign capital. With this background, the PPP mode has already been widely accepted and implemented in various infrastructure sectors, including transportation, power plants, water utilities, and so forth. 
The risks associated with PPP projects in different infrastructure sectors are different. This research is based on an extensive literature review, through which 34 risk factors were identified, and a tworound Delphi survey, conducted from October 2008 to February 2009, to assess the probability of occurrence and severity of each risk factor. Three additional risk factors were suggested by the respondents, bringing the total risk factors to 37. Based on the Delphi survey results, a structured interview questionnaire was designed, and face-to-face interviews were carried out during May 2009 with eight frontline project teams in the Chinese water supply sector. The interviews revealed 16 CRFs for water PPP projects in China. By comparing the 37 risk factors, further analysis found that completion risk, inflation, and price change risk have a higher impact on Chinese water PPP projects, whereas government corruption, an imperfect law and supervision system, as well as a change in market demand have a lower impact on the water supply sector. The findings of this study provide a better understanding for the government and private investors who participate in the enormous Chinese water market through the PPP mode.

\section{Acknowledgments}

The study described in this paper was fully supported by a joint grant from the Research Grants Council of the Hong Kong Special Administrative Region, China (Project No. N_PolyU 514/07) and the National Science Foundation Council Research Grant of China (Project No. 70731160634). This paper forms part of the research project titled "Developing an Equitable Risk Sharing Mechanism for Public Private Partnership Projects in the People's Republic of China” from which other deliverables have been produced with different objectives/scope but that share a common background and methodology. The authors also wish to acknowledge the contributions of other team members, including D. W. M. Chan, J. F. Y. Yeung, E. Cheung, E. W. M. Lam, Y. Xu, and T. Peng. Thanks are also due to the respondents and interviewees of this research study.

\section{References}

Abdul-Aziz, A. R. (2001). “Unraveling of BOT scheme: Malaysia’s Indah water consortium.” J. Constr. Eng. Manage., 10.1061/(ASCE)0733-9364(2001)127:6(457), 457-460.

Başaran, E. (2012). "Experience of Turkey in public private partnerships for infrastructure development.” T.R. Prime Ministry, State Planning Organization, Yücetepe-Ankara, Turkey, 〈http://www.oecd.org/mena/investment/39303323.pdf 〉 (Apr. 25, 2012).

Bayliss, K. (2002). "Water privatisation in SSA: Progress, problems and policy implications." Development Studies Association Annual Conf., Univ. of Greenwich, England.

Beech, R. (1999). “Go the extra mile: Use the Delphi technique.” J. Nurs. Manage., 7, 281-288.

Chan, A. P. C., Lam, P. T. I., Chan, D. W. M. M., Cheung, E., and Ke, Y. (2010). "Potential obstacles to successful implementation of public private partnerships in Beijing and the Hong Kong special administrative region.” J. Manage. Eng., 10.1061/(ASCE)0742597X(2010)26:1(30), 30-40.

Chan, A. P. C., Yung, E. H. K., Lam, P. T. I., Tam, C. M., and Cheung, S. O. (2001). “Application of Delphi method in selection of procurement systems for construction projects.” Constr. Manage. Econ., 19(7), 699-718.

Chen, C. (2009). "Can the pilot BOT project provide a template for future projects? A case study of the Chengdu No. 6 water plant B project.” Int. J. Proj. Manage., 27(6), 573-583.

Chen, C., and Doloi, H. (2008). “BOT application in China: Driving and impeding factors.” Int. J. Proj. Manage., 26(4), 388-398.

Cheung, E., and Chan, A. P. C. (2011). "Risk factors of public-private partnership projects in China: Comparison between the water, power, and transportation sectors.” J. Urban Plann. Dev., 10.1061/(ASCE)UP.1943-5444.0000086, 409-415. 
Choi, J.-H., Chung, J., and Lee, D.-J. (2010). “Risk perception analysis: Participation in China’s water PPP market.” Int. J. Proj. Manage., 28(6), 580-592.

Dailami, M., and Klein, M. U. (1997). "Government support to private infrastructure projects in emerging markets: In dealing with public risk in private infrastructure.” World Bank, Washington, DC, 21-42.

Delmon, J. (2009). Private sector investment in infrastructure: Project finance, PPP projects and risk, 2nd Ed., Kluwer Law International, Alphen aan den Rijn, Netherlands.

Dickey, J. W., and Watts, T. M. (1978). Analytic techniques in urban and regional planning, Chapter 13, McGraw-Hill, New York, 216-233.

Edmunds, H. (1999). The focus group research handbook, NTC Business Books, Chicago.

Goldstein, N. (1975). “A Delphi on the future of the steel and ferroalloy industries.” The Delphi techniques and applications, Addison Wesley, Reading, MA, 210-226.

GWI. (2004). “French reveal china strategy.” Global Water Intelligence, Vol. 5, No. 5, 〈http://www.globalwaterintel.com/archive/5/5/general/french-reveal-china-strategy.html〉 (Mar. 15, 2014).

Haarmeyer, D., and Mody, A. (1997). “Private capital in water and sanitation.” Finance \& development, World Bank, Washington, DC.

Haarmeyer, D., and Mody, A. (1998). "Tapping the private sector: Approaches to managing risk in water and sanitation.” World Bank, Washington, DC.

Hall, D. (2001). "Water in public hands-Public sector water management, a necessary option.” PSIRU Rep., 〈http://www.psiru.org/reports/2001-06-W-public.doc〉 (Apr. 25, 2012).

Hall, D., and Lobina, E. (2001). "Private to public: International lessons of water remunicipalisation in Grenoble, France.” PSIRU Rep., 〈http://www.psiru.org/reports/2001-08-W-Grenoble.doc〉 (Apr. 25, 2012).

Hall, D., and Lobina, E. (2004). "Private and public interests in water and energy.” Nat. Resour. Forum, 28(4), 268-277.

Hall, D., and Lobina, E. (2005). “The relative efficiency of public and private sector water.” Report commissioned by Public Services International (PSI), 〈http://www.psiru.org/reports/relativeefficiency-public-and-private-sector-water (Mar. 15, 2014).

Hallowell, M. R. (2009). “Techniques to minimize bias when using the Delphi method to quantify construction safety and health risks.” Construction Research Congress 2009, 1489-1498.

Hassanein, A. A. G., and Khalifa, R. A. (2007). "Financial and operational performance indicators applied to public and private water and wastewater utilities.” Eng. Constr. Archit. Manage., 14(5), 479-492.

Hemming, R., and Ali, M. M. (1988). "Privatization and public enterprises.” Occasional Paper 56, International Monetary Fund, Washington, DC.

Idelovitch, E., and Klas, R. (1997). "Private sector participation in water supply and sanitation in Latin America.”World Bank,Washington, DC.

Ke, Y. J., Wang, S. Q., Chan, A. P. C., and Lam, P. T. I. (2010). "Preferred risk allocation in China's public-private partnership projects.” Int. J. Proj. Manage., 28(5), 482-492.

Lee, S. (2003). "Expansion of the private sector in the Shanghai water sector." Occasional Paper No.53, School of Oriental and African Studies, Univ. of London, U.K, 〈http://www.soas.ac.uk/water/publications/papers/file38396.pdf) (Mar. 15 2014).

Lee, T., and Sung, W. L. K. (1998). “China’s new BOT program: Some reflections from a legal perspective.” Proc., 1998 China BOT Forum, II, Beijing, 122-134.

Li, B., Akintoye, A., Edwards, J. P., and Hardcastle, C. (2005). “The allocation of risk in PPP/PFI construction projects in the UK.” Int. J. Proj. Manage., 23(1), 25-35.

Linstone, H., and Turoff, M. (1975). The Delphi method: Techniques and applications, Addison Wesley, Reading, MA, 3-12. 
Linstone, H., and Turoff, M. (2002). “The Delphi method: Techniques and applications.” Information Systems Dept., New Jersey Institute of Technology, Newark, NJ.

Lobina, E. (2000). “Cochabamba-Water war.” Focus, 7(2), 1-7.

Lobina, E. (2005). "Problems with private water concessions: A review of experiences and analysis of dynamics.” Int. J. Water Resour. Dev., 21(1), 55-87.

Manoliadis, O., Tsolas, O., and. Kakou, A. (2006). "Sustainable construction and drivers of change in Greece: A Delphi study.” Constr. Manage. Econ., 24(2), 113-120.

Marin, P. (2009). "What is the actual performance of public-private partnerships for urban utilities in developing countries?” Private Sect. Dev., 2, 3-4.

Mehta, R., and Sivadas, E. (1995). "Comparing response rates and response content in mail versus electronic surveys.” J. Market Res. Soc., 4(37), 429-440.

Meng, X., Zhao, Q., and Shen, Q. (2011). "Critical success factors for transfer-operate-transfer urban water supply projects in China.” J. Manage. Eng., 10.1061/(ASCE)ME.1943-5479.0000058, 243-245.

Ministry of Construction. (2005). Yearbook of Chinese urban construction 2004, China’s Construction Press, Beijing.

Moglia, M., Burn, S., and Tjandraatmadja, G. (2009). "Vulnerability of water services in Pacific island countries: Combining methodologies and judgment.” Water Sci. Technol., 60(6), 1621-1631.

Morgan, D. L. (1998). The focus group guidebook (focus group kit 1), Sage Publications, Beverly Hills, CA.

National Bureau of Statistics (NBS). (2007). China statistical yearbook 2007, Beijing.

Peninsula Research and Development Support Unit (RDSU). (2003). "Enhancing questionnaire response rates.” R\&D Hospital, Exeter, UK.

Pribadi, K. S., and Pangeran, M. H. (2007). "Important risks on public private partnership scheme in water supply investment in Indonesia.” Proc., 1st Int. Conf. of European Asian Civil Engineering Forum, Univ. Pelita Harapan, Indonesia.

Public Private Partnership Centre. (2012). A PPP manual for local government units (LGUs): Developing projects for local governments units, Vol. 2, Government of Phillippines.

Rall, J., Reed, J. B., and Farber, N. J. (2010). "Public-private partnerships for transportation: A toolkit for legislators.” National Conf. of State Legislatures, The Forum for America’s Ideas, Washington, DC.

Rivera, D. (1996). "Private sector participation in the water supply and waste water sector: Lessons from six developing countries.” Directions in development series, World Bank, Washington, DC.

Rixon, A., Smith, T. F., McKenzie, B., Sample, R., Scott, P., and Burn, S. (2007). "Perspectives on the art of facilitation: A Delphi study of natural resource management facilitators.” Aust. J. Environ. Manage., 14(3), 179-191.

Robinson, J. B. L. (1991). “Delphi technology for economic impact assessment.” J. Transp. Eng., 10.1061/(ASCE)0733-947X(1991)117:3(335), 335-349.

Russell, E., Sr. (1993). "Rating countermeasures for mitigation of hazardous materials incidents.” J. Transp. Eng., 10.1061/(ASCE)0733-947X(1993)119:2(211), 211-225.

Sachs, T., Tiong, L. K. R., and Wang, S. Q. (2007). "Analysis of political risks and opportunities in public private partnerships (PPP) in China and selected Asian countries: Survey results.” Chinese Manage. Stud., 1(2), 126-148.

Sheehan, K. B., and Hoy, M. G. (1997). "E-mail surveys: Response patterns, process and potential.” Proc., 1997 Conf. of the American Academy of Advertisers, St. Louis, 231.

Shen, L. Y., Platten, A., and Deng, X. P. (2006). "Role of public private partnership to manage risks in public sector projects in Hong Kong.” Int. J. Proj. Manage., 24(7), 587-594. 
SPSS. (2003). "How to get more value from your survey data-Discover four advanced analysis techniques that make survey research more effective-Technical report.” International Business Machines Corporation (IBM), Armonk, NY, 〈http://www.spss.com/no/products/spssdimensions/morevalue.pdf〉 (Sep. 13, 2013).

Thomas, A. V., Kalidindi, S. N., and Ananthanarayanan, K. (2003). "Risk perception analysis of BOT road project participants in India.” Constr. Manage. Econ., 21(4), 393-407.

Tiong, L. K. R. (1995). “Risks and guarantees in BOT tender.” J. Manage. Eng., 10.1061/(ASCE)0733-9364(1995)121:2(183), 183-188.

Toor, S. U. R., and Ogunlana, S. O. (2008). "Critical COMs of success in large-scale construction projects: Evidence from Thailand construction industry.” Int. J. Proj. Manage., 26(4), 420430.

Wang, S. Q., and Ke, Y. J. (2009). "Case study IV_-Laibin B power project-The first stateapproved BOT project in China.” Public private partnership in infrastructure development, $\mathrm{H}$. W. Alfen, ed., Bauhaus- Univ. Weimar, Weimar, Germany.

Wang, S. Q., Tiong, L. K. R., Ting, S. K., and Ashley, D. (1999). "Political risks: Analysis of key contract clauses in China’s BOT project.” J. Constr. Eng. Manage., 10.1061/(ASCE)07339364(1999)125:3 (190), 190-197.

Wang, S. Q., Tiong, L. K. R., Ting, S. K., and Ashley, D. (2000). "Evaluation and management of political risks in China’s BOT projects.” J. Constr. Eng. Manage., 10.1061/(ASCE)07339364(2000)126:3(242), 242-250.

Wang, Y. D. (2002). “BOT trap.” Global entrepreneur, China Writer Press (Group), Beijing (in Chinese).

Wibowo, A., and Mohamed, S. (2010). "Risk criticality and allocation in privatized water supply projects in Indonesia.” Int. J. Proj. Manage., 28(5), 504-513.

Wiguna, I. P. A., and Scott, S. (2006). "Relating risk to project performance in Indonesian building contracts.” Constr. Manage. Econ., 24(11), 1125-1135.

World Bank. (2010). "Procurement arrangements applicable to PPP contracts financed under World Bank projects: Summary of guidance note.” 〈worldbank.org/:::

/Summary_of_Guidance_Note.pptx〉(Apr. 20, 2012).

Xenidis, Y., and Angelides, D. (2005). “The financial risks in build-operate-transfer projects.” Constr. Manage. Econ., 23(4), 431-441.

Xu, Y., Chan, A. P. C., and Yeung, J. F. Y. (2010a). "Developing a fuzzy risk allocation model for PPP projects in China.” J. Constr. Eng. Manage., 10.1061/(ASCE)CO.1943-7862.0000189, 894-903.

Xu, Y., Yeung, J. F. Y., Chan, A. P. C., Chan, D. W. M., Wang, S. Q., and Ke, Y. (2010b). "Developing a risk assessment model for PPP projects in China-A fuzzy synthetic evaluation approach.” Autom. Constr., 19(7), 929-943.

Yuan, J., Skibniewski, M. J., and Li, Q. (2008). "Managing the performance of public private partnership projects to achieve value for money: Key performance indicators selection.” CIB W112 Int. Conf. on Multi-National Construction Projects: Securing High Performance Through Cultural Awareness and Dispute Avoidance, Shanghai, China.

Zayed, T. M., and Chang, L. M. (2002). "Prototype model for build-operate-transfer risk assessment.” J. Manage. Eng., 10.1061/(ASCE)0742-597X(2002)18:1(7), 7-16.

Zhang, X. Q., and Kumaraswamy, M. M. (2001). "BOT-based approaches to infrastructure development in China.” J. Infrastruct. Syst., 10.1061/(ASCE)1076-0342(2001)7:1(18), 1825.

Zhong, L. J., Arthur, P. J. M., and Tao, F. (2008). "Public-private partnerships in China's urban water sector.” Environ. Manage., 41(6), 863-877.

Zhong, L. J., Wang, X., and Chen, J. (2006). "Private participation in China's wastewater service under the constraint of charge rate reform.” Water Sci. Technol.: Water Supply, 6(5), 77-83. 